\title{
Influence of Fertility Levels and Plant Growth Retardants on Growth and Productivity of Wheat (Triticum aestivum L.) in Jharkhand
}

\author{
Naiyar Ali ${ }^{*}$, P. Alam ${ }^{1}$, Akhilesh Sah', Tajwar Izhar $^{3}$ and Sanjay Kumar ${ }^{1}$ \\ ${ }^{1}$ Department of Agronomy, ${ }^{2}$ Akhilesh Sah, ZRS (BAU), Chianki, Palamu, India \\ ${ }^{3}$ Department of Forage Breeding (LPM), RVC, Birsa Agricultural University, Kanke, \\ Ranchi, Jharkhand, India \\ *Corresponding author
}

\section{Keywords}

$\mathrm{CCC}$,

Tebuconazole, Net Return, B:C Ratio, Plant Growth retardants, Wheat, Grain yield

Article Info

Accepted:

18 December 2020

Available Online:

10 January 2021
The study was conducted during rabi 2017-18 and 2018-19 at Crop Research Farm , Eastern Section of Birsa Agricultural University, Ranchi-834006 (Jharkhand) to evaluate the Fertility levels and application of growth regulators on growth of wheat (Triticum aestivum L.) with objective to achieve yield maximization. The experiment was laid out in split plot design with three replications. The treatments consisted of four fertility levels absolute Control;100\% (Recommended Dose of Fertilizer);RDF150:60:40;150\%RDF and 150\%RDF+15tFYM/ha) in main plot and four growth regulators (Two sprays each of water, CCC $(0.2 \%)$, Tebuconazole $(0.1 \%) ; \mathrm{CCC}(0.2 \%)+$ Tebuconazole $(0.1 \%)$. The soil of the experimental field was clay loam in texture, acidic in reaction, low in available nitrogen, phosphorus and medium available potassium. Results revealed that application of $150 \% \mathrm{RDF}+15 \mathrm{tFYM}$ led to higher plant height, dry matter accumulation and lodging score of wheat at harvest in both the years. The combined application of (CCC)+Tebuconazole reduced the plant height of wheat by $22.0 \%$ and $20.3 \%$ over water spray during 2016-17 and 2017-18 respectively. The minimum mean lodging score mean 1.0 and 1.5 were recorded with application of CCC and Tebuconazole during 2016-17 and 2017-18 respectively. The significantly higher number of spike $\left(368 \& 388 \mathrm{~m}^{-2}\right)$, spike length $(11.6 \& 12.40 \mathrm{~cm})$, number of spikelets/spike(21.40\&22.50) and test weight $(39.13 \& 40 \mathrm{~g})$ were registered with application of $150 \% \mathrm{RDF}+15 \mathrm{tFYM}$ during 2016-17 and 2017-18 respectively as compared to $100 \%$ RDF. The combined spray of CCC+Tebuconazole enhanced the test weight by $5.6 \% \& 3.7 \%$ over water spray during both the years $2016-17$ and 2017-18, respectively. The significantly maximum grain, straw and biomass yield of wheat were recorded with $150 \% \mathrm{RDF}+15 \mathrm{tFYM}$ which were $5.8 \& 17.03 \%, 16.3 \& 32.2 \%$, and 10.82 $\& 24.7 \%$ higher over $100 \%$ RDF during both the years $2016-17$ and $2017-18$, respectively. The grain yield of wheat due to combine application CCC and Tebuconazole was found significantly higher $(10.84$ and $11.15 \%)$ during both the years. There were no differences in straw and biomass yields of wheat due to different growth regulators.

\section{Introduction}

Worldwide, wheat (Triticum aestivum L.) is grown in a majority of the countries and finds a significant share in consumption basket. Globally, wheat is the largest cultivated with an estimated area of 220.19 million hectares (mha). In India, during 2018-19 Rabi season, 
Wheat was cultivated in $29.55 \mathrm{mha}$, constituting 24.35 per cent of the total crop acreage, production $101.20 \mathrm{M}$ tones and an average productivity of $3424 \mathrm{~kg} \mathrm{ha}{ }^{-1}$ (Anonymous 2019). Jharkhand has an area of just 2.21 lakh ha, an productivity of $18.49 \mathrm{qha}^{-}$ 1 (Anonymous 2019). The productivity of wheat in Jharkhand is very low as compared to national level. One of the main reasons of this low productivity in addition to restricted irrigation is imbalance use of chemical fertilizers which results in lower yield and also adversely affects the soil health. By use of sufficient quantity of organic manure in addition to chemical fertilizers, soil health can be improved. Fertilizers responsive varieties have important role in increasing yield. Hence it is urgent need to fine tune the fertilizers and manurial requirement of high yielding varieties of wheat. So one of the popular variety HD2967 has been taken in above experiment.

A chronic worldwide constraint to sustainable wheat production is lodging that often decreases photosynthetic ability and biomass production, deteriorates seed quality, and creates difficulties to harvest operations(Zhang et al.,2017) Wheat and rice are highly prone to lodging during late vegetative growth and at reproductive stages ( Shah et al., 2019) exaggerating the need for additional research efforts Lodging in cereals can be defined as the permanent displacement of stems from the vertical position, which could result from either plastic failure of the stem base (stem lodging) or failure of the belowground anchorage system (Berry et al., 2004). The key reasons responsible for wheat lodging are increase in weight of mature ears due to water accumulation, occurrence of high speed winds at grain filling stage, wide use of flat planting and flood irrigation and the lack of acceptable cultivars of wheat that are lodging tolerant at higher nitrogen $(\mathrm{N})$ rates etc. (Taiz and Zeiger 2004, Stachecki et al.,
2004). The lodging in wheat can be controlled by using short lodging tolerant cultivars and by applying growth retardant chemicals etc. (Rodrigues et al., 2003).The semi-dwarf wheat cultivars can limit lodging under moderate levels of inputs, especially fertilizer and irrigation. Lodging resistance of these improved semi dwarf cultivars, resulting from shorter and stiffer straw, is markedly expressed at moderate levels of $\mathrm{N}$ fertility (Pinthus, 1974). Under certain agronomic conditions, however, even semi dwarf wheat cultivars have been observed to lodge under Indian condition (Tripathi et al., 2003). This form of lodging which is most common with well-managed wheat crop occurs near or after flowering and is primarily the result of wind during or soon after irrigation or rainstorms (Hobbs, 2007). The reduction in grain yield caused by lodging ranged from 7 to $35 \%$ with greatest effect when lodging occurred within the month after anthesis, is most commonly reported under Indian condition. The yield potential of high yielding genotypes of wheat under irrigated and high input rates could be achieved consistently and efficiently by finding suitable solutions of lodging problem. In this context, the use of growth retardants found to be most effective for managing the problem of lodging (Zhang et al., 2017). Growth retardants are chemical substances that have the potential to alter structural or vital processes inside the plant by modifying hormone balance to increase yield, improve quality or facilitate harvesting through checking lodging especially in cereals (Zhang et al., 2017). Lodging preventers (plant height retardants) are generally antagonistic to gibberellin and act by altering their metabolism (Peake et al., 2014) and for aforesaid reason they are frequently called anti-gibberellin. The nature and extent of lodging are closely related to height of the stem, which can be modified by application of growth inhibitors (Peng et al., 2014). Application of growth inhibitors, like 
ethephon (2-chloro ethyl phosphonic acid) or CCC (Chlormequat Chloride), was reported to be useful in decreasing plant height and subsequently reducing lodging (Niu et al., 2012).Therefore, the objective of present study was to determine the effects of different fertility levels and lodging preventers on growth behavior, productivity in sub humid conditions.

\section{Materials and Methods}

The study was conducted during two consecutive rabi season of 2017-18 and 201819 at Crop Research Farm, Eastern Section of Birsa Agricultural University, Ranchi-834006 (Jharkhand) to evaluate the effect of nutrient management and application of growth regulators on growth of wheat (Triticum aestivum L.) with objective to achieve yield maximization under All India Coordinated Wheat and Barley Improvement Project. The experimental site situated in North Eastern Plain Zones of Jharkhand having average annual rainfall of zone is $1440.0 \mathrm{~mm}$ of which about $85 \%$ is received during June to September with erratic distribution over time and space.

The soil of the experimental field was clay loam in texture, acidic in reaction $(\mathrm{pH} ; 5.8)$, low in organic carbon and nitrogen, phosphorus and medium exchangeable potassium. The experiment was laid out in split plot design and consist of four fertility levels, viz. Control (No fertilization), 100\% RDF (Recommended dose of fertilizer: 150:60:40 kg/ha), 150\% RDF (225:90:60 $\mathrm{kg} / \mathrm{ha})$ and 150\% RDF (225:90:60 kg/ha)+15t $\mathrm{FYM} / \mathrm{ha}$ in main plots and four plant growth regulators, viz. control (water spray), $0.2 \%$ spray of Chlormequat Chloride(CCC) $0.1 \%$ spray of Tebuconazole and a combined spray of Chlormequat Chloride +Tebuconazole in sub plots, replicated thrice. Growth regulators were used twice i.e. at first node and flag leaf stages. Field preparation included one deep ploughing by mould board plough followed by 2 cross harrowing and planking. The wheat variety HD-2967 was sown during second week of November with a recommended seed rate of $100 \mathrm{~kg} / \mathrm{ha}$. A well rotten $15 \mathrm{tonn} / \mathrm{ha}$ of FYM was applied before 15 days the sowing of crops as per treatment and well mixed in the soil. During both the seasons 1/3rd quantity of total $\mathrm{N}$ and whole amount of $\mathrm{P}_{2} \mathrm{O}_{5}$ and $\mathrm{K}_{2} \mathrm{O}$ were applied as basal at sowing, while remaining $2 / 3^{\text {rd }}$ quantity of $\mathrm{N}$ were applied in two split of equal quantity, i.e. $1 / 3$ rd at first irrigation and 1/3rd at second irrigation. Crop was raised under irrigated condition and a total of five irrigations were applied at critical growth stages. Crop protection measures were followed as and when required.

The growth and yield attributes were recorded as per the standard procedure by sampling from three places in each plot. The net plots, leaving the one border rows on the rows direction and half meter on opposite direction of the plots of wheat were harvested manually with sickle. The produce was kept for sun drying for some days in field and after drying; the biological yield was recorded and expressed in $\mathrm{q} / \mathrm{ha}$. After threshing the bundles from each plot, the grains were cleaned, dried and weighed. The grain yield was expressed in $q /$ ha. Straw yield was obtained by subtracting the grain yield from the weight of total biological yield for individual plots and was expressed in tonnes/ha. Lodging was scored with the formula $\{(\%$ plot area lodged $\times$ angle of lodging from vertical position)/90 described by Fischer and Stapper (1987).All data recorded were analyzed with the help of analysis of variance (ANOVA) technique (Gomez and Gomez 1984).The least significant test was used to decipher the main and interaction effects of treatments at $5 \%$ level of significance $(\mathrm{P}<0.05)$. 


\section{Results and Discussion}

Effect of fertility levels and growth regulators on growth parameters and lodging of wheat

The nutrient management had significant effect on plant height of wheat at harvest. At harvest the crop fertilized with 150\% RDF+FYM attained significantly maximum plant height $(91.50 \& 91.0 \mathrm{~cm})$ over control $(61.75 \& 65.08 \mathrm{~cm})$ during both years respectively. However, the crop supplied with $150 \%$ RDF produced statistically similar plant height compared to $150 \% \mathrm{RDF}+\mathrm{FYM}$ during both the years. The nutrient management levels also realized significant effect on dry matter accumulation of wheat (Table 1) at harvest during both the years. At harvest stage, crop fertilized with $150 \%$ RDF+FYM recorded significantly highest dry matter accumulation over control and 100\% RDF. However, the crop fertilized with $150 \%$ RDF produced statistically similar dry matter compared to $150 \% \mathrm{RDF}+\mathrm{FYM}$ during both the years. The application of $150 \%$ $\mathrm{RDF}+\mathrm{FYM}$ enhanced the dry matter of crop with the magnitude of 13.20 and $11.30 \%$ at harvest) over 100\% RDF during 2016-17 and 2017-18. The maximum lodging score was found due to application of $150 \% \mathrm{RDF}+\mathrm{FYM}$ during both the years. The major nutrients (NPK) are important constituents for cell division and cell elongation and their optimum availability with integrated use of organic and inorganic nutrient sources led to higher plant growth. Higher availability of these nutrients might improve photosynthetic area of plants that cumulatively contribute to higher dry matter accumulation.

Table.1 Effect of fertility levelsand plant growth regulators on growth and lodging on wheat

\begin{tabular}{|c|c|c|c|c|c|c|}
\hline \multirow[t]{2}{*}{ Treatments } & \multicolumn{2}{|c|}{$\begin{array}{l}\text { Plant height at } \\
\text { maturity }(\mathrm{cm})\end{array}$} & \multicolumn{2}{|c|}{$\begin{array}{c}\text { Dry matter } \\
\text { accumulation at } \\
\text { maturity }\left(\mathrm{gm}^{-2}\right)\end{array}$} & \multicolumn{2}{|c|}{ Lodging scores } \\
\hline & $\frac{1}{b}$ & $\frac{\frac{\infty}{1}}{\frac{1}{\pi}}$ & $\frac{n}{b}$ & $\frac{\frac{\infty}{1}}{\frac{1}{5}}$ & $\frac{a}{b}$ & $\frac{\frac{\infty}{1}}{\frac{1}{2}}$ \\
\hline \multicolumn{7}{|l|}{ Nitrogen levels } \\
\hline 1.Absolute control & 61.75 & 65.08 & 850.50 & 880.40 & 0.0 & 0.0 \\
\hline 2. RDF (150:60:40) & 87.17 & 88.92 & 1450.22 & 1510.20 & 0.0 & 0.0 \\
\hline 3. $150 \%$ RDF & 90.60 & 90.75 & 1560.12 & 1590.40 & 12.8 & 15.8 \\
\hline 4.150\% RDF+15 t FYM & 91.50 & 91.0 & 1580.14 & 1630.80 & 14.8 & 16.8 \\
\hline S.Em \pm & 0.98 & 0.76 & 22.24 & 24.82 & - & - \\
\hline $\mathrm{CD}(\mathbf{P}=0.05$ & 3.41 & 2.62 & 54.91 & 58.82 & - & - \\
\hline \multicolumn{7}{|l|}{ Plant growth regulators } \\
\hline 1. water sprays & 98.50 & 97.50 & 1382.91 & 1412.12 & 8.0 & 9.8 \\
\hline 2. CCC & 79.17 & 81.08 & 1405.04 & 1420.14 & 4.4 & 5.8 \\
\hline 3. Tubaconazole & 78.33 & 79.50 & 1420.50 & 1480.24 & 7.8 & 8.4 \\
\hline 2. CCC+Tubaconazole & 76.83 & 77.67 & 1450.20 & 1510.20 & 1.0 & 1.5 \\
\hline S.Em \pm & 1.74 & 2.28 & 21.40 & 23.60 & - & - \\
\hline $\mathrm{CD}(\mathrm{P}=0.05$ & 5.08 & 6.65 & 45.02 & 48.20 & - & - \\
\hline
\end{tabular}


Table.2 Effect of fertility levelsand plant growth regulators on yield attributes of wheat

\begin{tabular}{|c|c|c|c|c|c|c|c|c|c|c|}
\hline \multirow[t]{2}{*}{ Treatments } & \multicolumn{2}{|c|}{ Spike $\mathbf{m}^{-2}$} & \multicolumn{2}{|c|}{$\begin{array}{l}\text { Length of spike } \\
\text { (cm) }\end{array}$} & \multicolumn{2}{|c|}{ No. of grains spike } & \multicolumn{2}{|c|}{ No. of spikelets spike } & \multicolumn{2}{|c|}{$\begin{array}{l}\text { Test weight } \\
\text { (g) }\end{array}$} \\
\hline & $\frac{\sqrt{b}}{\frac{1}{\sigma}}$ & $\frac{\frac{\infty}{1}}{\frac{\pi}{2}}$ & $\frac{\frac{n}{b}}{b}$ & $\frac{\infty}{\frac{\infty}{1}} \frac{i}{\sigma}$ & $\begin{array}{l}\frac{1}{1} \\
\text { bे } \\
\text { ते }\end{array}$ & $\frac{\frac{\infty}{1}}{\frac{1}{\sigma}}$ & $\frac{n}{b}$ & $\frac{\frac{\infty}{1}}{\frac{1}{0}}$ & 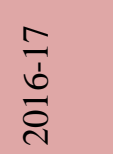 & $\frac{\infty}{\frac{\infty}{1}}$ \\
\hline \multicolumn{11}{|l|}{ Nitrogen levels } \\
\hline 1.Absolute control & 169 & 166 & 6.50 & 7.20 & 16.9 & 11.94 & 13.30 & 14.60 & 35.12 & 34.53 \\
\hline 2. RDF (150:60:40) & 339 & 335 & 10.10 & 9.98 & 33.90 & 32.76 & 18.60 & 17.90 & 38.54 & 38.13 \\
\hline $3.150 \%$ RDF & 354 & 360 & 11.2 & 11.30 & 35.40 & 33.87 & 20.50 & 21.20 & 38.98 & 39.11 \\
\hline $\begin{array}{l}4.150 \% \text { RDF }+15 \text { t } \\
\text { FYM ha }{ }^{-1}\end{array}$ & 368 & 388 & 11.6 & 12.40 & 36.80 & 34.06 & 21.40 & 22.50 & 39.13 & 40.13 \\
\hline S.Em \pm & 7.35 & 10.76 & 0.201 & 0.241 & 0.98 & 1.0 & 0.402 & 0.512 & 0.16 & 0.44 \\
\hline $\mathrm{CD}(\mathrm{P}=0.05$ & 25.43 & 37.23 & 0.880 & 1.210 & 3.41 & 3.44 & 1.150 & 1.410 & 0.54 & 1.25 \\
\hline \multicolumn{11}{|l|}{ Plant growth regulators } \\
\hline 1. water sprays & 303 & 306 & 10.80 & 9.80 & 26.17 & 26.32 & 18.90 & 18.20 & 37.85 & 37.72 \\
\hline 2. $\mathrm{CCC}$ & 306 & 307 & 10.90 & 11.80 & 28.42 & 28.75 & 20.10 & 19.40 & 37.91 & 37.88 \\
\hline 3. Tubaconazole & 308 & 315 & 11.50 & 11.60 & 28.90 & 29.76 & 19.10 & 18.40 & 38.05 & 38.19 \\
\hline 2. CCC+Tubaconazole & 313 & 321 & 12.20 & 11.52 & 27.83 & 27.80 & 20.18 & 20.20 & 39.96 & 39.11 \\
\hline S.Em \pm & 7.08 & 9.48 & 0.208 & 0.280 & 0.92 & 1.34 & 0.406 & 0.506 & 0.77 & 0.43 \\
\hline $\mathrm{CD}(\mathrm{P}=0.05$ & NS & NS & NS & NS & NS & NS & NS & NS & 2.10 & 1.25 \\
\hline
\end{tabular}

Table.3 Effect of fertility levelsand plant growth regulators on yield and Harvest Index of wheat

\begin{tabular}{|c|c|c|c|c|c|c|c|c|}
\hline \multirow[t]{2}{*}{ Treatments } & \multicolumn{2}{|c|}{$\begin{array}{l}\text { Grain yield } \\
\text { qha }^{-1}\end{array}$} & \multicolumn{2}{|c|}{ Straw yield qha ${ }^{-1}$} & \multicolumn{2}{|c|}{ Biomass qha $^{-1}$} & \multicolumn{2}{|c|}{ Harvest Index(\%) } \\
\hline & $\frac{\sqrt{7}}{\sqrt{b}}$ & $\frac{\infty}{\frac{\infty}{1}}$ & $\frac{\sqrt{7}}{\frac{1}{0}}$ & $\frac{\frac{\infty}{1}}{\frac{1}{2}}$ & 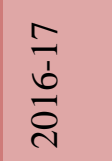 & $\frac{\infty}{\frac{\infty}{1}}$ & 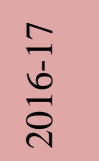 & $\frac{\infty}{\frac{\infty}{1}}$ \\
\hline \multicolumn{9}{|l|}{ Nitrogen levels } \\
\hline 1.Absolute Conrtrol & 6.48 & 6.87 & 7.82 & 7.13 & 14.30 & 14.0 & 45.3 & 48.0 \\
\hline 2. RDF (150:60:40) & 46.78 & 43.02 & 43.32 & 41.98 & 90.10 & 85.0 & 51.9 & 50.6 \\
\hline $3.150 \% \mathrm{RDF}$ & 46.20 & 47.12 & 47.68 & 51.88 & 93.88 & 99.0 & 49.2 & 47.6 \\
\hline 4.150\% RDF+15 t FYM ha-1 & 49.48 & 50.40 & 50.37 & 55.6 & 99.85 & 106.0 & 49.5 & 47.7 \\
\hline S.Em \pm & 0.69 & 0.82 & 0.70 & 0.89 & 1.63 & 3.68 & 1.80 & 1.60 \\
\hline $\mathrm{CD}(\mathrm{P}=0.05$ & 2.38 & 2.85 & 2.45 & 2.80 & 5.63 & 12.74 & NS & NS \\
\hline \multicolumn{9}{|l|}{ Growth Regulators } \\
\hline 1. water sprays & 34.21 & 34.97 & 36.52 & 40.03 & 70.73 & 75.0 & 48.4 & 46.6 \\
\hline 2. $\mathrm{CCC}$ & 36.09 & 37.05 & 35.71 & 39.95 & 71.80 & 77.0 & 50.3 & 48.1 \\
\hline 3. Tubaconazole & 36.72 & 37.52 & 40.99 & 43.48 & 77.71 & 81.0 & 47.2 & 46.32 \\
\hline 2. CCC+Tubaconazole & 37.92 & 38.87 & 39.96 & 42.13 & 77.88 & 81.6 & 48.7 & 48.0 \\
\hline S.Em \pm & 0.66 & 0.95 & 1.60 & 1.80 & 1.53 & 3.38 & 1.48 & 1.51 \\
\hline $\mathrm{CD}(\mathrm{P}=0.05$ & 1.92 & 2.78 & NS & NS & 4.45 & NS & NS & NS \\
\hline
\end{tabular}


The results of study are in accordance with the results of Joergensen et al., 2010. The combined application of CCC + Tebuconazole resulted in significantly lowest plant height compared to water spray but statistically at par with other growth retardants. The combined application of CCC + Tebuconazole reduced the plant height of wheat with the magnitude of 22.0 and $20.3 \%$ as compared to the water spray during both the years, respectively. However, all the growth retardant found statistically at par for dry matter accumulation. Plant height and strength of basal internodes are closely related to lodging resistance (Zhang et al., 2010 and Wei et al., 2008). Based on the above results, it may be suggested that, the combined application of CCC + Tebuconazole can avoid risk of lodging occurred by altering the plant height. The results of study are valuable for enhancing lodging resistance by reducing plant height of wheat to prevent lodging and improving grain yield and quality.

\section{Effect of fertility levels and growth retardants on yield attributes of wheat}

The data indicated that nutrient management practices had significant effect on yield attributes of wheat (number of effective spike $/ \mathrm{m}^{2}$, spike length and test weight) of wheat (Table 2). The significantly higher number of spike (368 and $388 / \mathrm{m}^{2}$ ), spike length $(11.60$ and $12.40 \mathrm{~cm})$, number of grains (36.80 and 34.06/spike) and test weight (39.13 and $40.13 \mathrm{~g})$ were registered with $150 \% \mathrm{RDF}+\mathrm{FYM}$ as compared to $100 \% \mathrm{RDF}$. Whereas, minimum number of spike (169 and $\left.166 / \mathrm{m}^{2}\right)$, spike length $(6.50$ and $7.20 \mathrm{~cm})$, number of grains (16.9 and 11.94 /spike and test weight (35.12 and $34.53 \mathrm{~g}$ ) were recorded under control during both the years, respectively. However, crop supplied with the $100 \%$ RDF and $150 \%$ RDF recorded statistically similar results for aforesaid yield attributes compared with $150 \mathrm{RDF}+\mathrm{FYM}$.
The optimal and balanced supply of nutrient (macro and micronutrient) from both the sources led to higher growth and development of plants and side by side improve the physical, chemical, biological and hydrological properties of soil which further provide an optimum environment for higher growth and development of plants reflected by higher yield attributes of plants (Behera $e t$ al., 2007).The number of spike and spike length under different growth retardant were found statistically at par, although highest values were recorded with combined use of CCC +Tebuconazole (Table 2). However, the growth regulators led significant effect on test weight as compared to water spray and the maximum values were recorded with the combined application of CCC +Tebuconazole during both the years. Similar results on wheat with the use of plant growth retardants were also reported by Rajala et al., (2002).

\section{Effect of fertility levels and growth retardants on crop productivity}

Present findings revealed that fertility levels had significant effect on wheat productivity (Table 3). The maximum grain and straw yield of wheat were recorded with $150 \% \mathrm{RDF}+$ FYM which were 50.87 and $12.26 \%$ and 50.31 and $15.92 \%$ higher compared to control and $100 \%$ RDF, respectively. However, the wheat crop fertilized using $150 \%$ RDF was found statistically at par with $150 \%$ RDF+ FYM. Similarly the mean total biomass (grain+straw) was also found maximum with application 150\% RDF+ FYM. It enhanced the biomass yield of wheat by 50.56 and $14.27 \%$ compared to control and $100 \%$ RDF, respectively. Similar to grain and straw yield, the crop fertilized using 150\% RDF yielded statistically similar biomass compared to $150 \%$ RDF+ FYM. This increment in crop productivity might be result of higher plant growth, dry matter accumulation and yield attributes with the combined application of 
organic and inorganic compared to when chemical fertilizer applied alone. Similar results were also reported by many other researchers which state that integration of chemical and organic sources led to higher crop productivity (Manna et al., 2003). Wheat yield (grain, straw and biomass) due to different growth retardant treatments were found statistically at par, although highest values of were recorded with combined use of CCC and Tebuconazole over others treatments. The magnitudes of increase in mean grain, straw yield and biological yield with the combined spray of CCC and Tebuconazole over water spray were 9.37, 3.57 and $6.24 \%$, respectively. These results are in close agreement with the results of earlier researchers (Tripathi et al., 2003) who stated that growth inhibitor significantly reduced plant height and simultaneously produced equal biomass over no application.

Based on the finding of two years it may be conclude that application of $150 \% \mathrm{RDF}+15 \mathrm{t}$ FYM/ha with CCC(Lihocin) + Tebuconazole (Folicur 430) resulted in significantly higher grain yield of wheat.

\section{References}

Anonymous. 2019. Agricultural statistics at a glance, Government of India

Behera U K, Sharma A R and Pandey H N. 2007. Sustaining productivity of wheatsoybean cropping system through integrated nutrient management practices on the Vertisols of central India. Plant and Soil. 297(2): 185-99.

Berry, P.M.; Sterling, M.; Spink, J.H.; Baker, C.J.; Sylvester-Bradley, R.; Mooney, S.J.; Tams, A.R.; Ennos, A.R2004.Understanding and reducing lodging in cereals. Adv. Agron. 84:217271.

Fischer, M. Stapper1987.Lodging effects on high yielding crops of irrigated semi- dwarf wheat Field Crops Research.17 :245-258.

Gomez K A and Gomez A A. 1984. Statistical Procedures for Agricultural Research. John Wiley \& Sons.

Hobbs, P., Sayre, K., and Ortiz-Monasterio, I. 1998. Increasing Wheat Yields Sustainability Through Agronomic Means. Mexico: CIMMYT.

Hobbs P R. 2007.Conservation agriculture: what is it and why is it important for future sustainable food production ? Journal of Agricultural Science. 145(2): 127-33.

Joergensen R G, Mäder P and Fliessbach A. 2010. Long-term effects of organic farming on fungal and bacterial residues in relation to microbial energy metabolism. Biology and Fertility of Soil 46: 303-7.

Manna M C, Ghosh P K and Ganguly T K. 2003. Comparative performance of four sources of enriched phosphocompost and inorganic fertilizer application on yield, uptake of nutrients and biological activity of soil under soybean-wheat rotation. Food Agriculture and Environment 1(2): 203-8.

Niu L Y, Feng S W, Ru Z G, Li G, Zhang Z P and Wang Z W. 2012. Rapid determination of single-stalk and population lodging resistance strengths and an assessment of the stem lodging wind speeds for winter wheat. Field Crops Research 139(1): 1-8.

Peake A S, Huth N I, Carberry P S, Raine S R and Smith R J. 2014. Quantifying potential yield and lodging-related yield gaps for irrigated spring wheat in subtropical Australia. Field Crops Research 158(2): 1-14.

Peng D, Chen X, Yin Y, Lu K, Yang W, Tang $\mathrm{Y}$ and Wang Z. 2014.Lodging resistance of winter wheat (Triticum aestivum L.): Lignin accumulation and its related enzymes activities due to the 
application of paclobutrazol or gibberellin acid. Field Crops Research 157: $1-7$.

Pinthus, M. J. (1973). Lodging in wheat, barley, and oats: the phenomenon, its causes, and preventive measures. $A d v$. Agron. 25:209-263

Rajala A, Peltonen-Sainio P, Onnela M and Jackson M. 2002. Effects of applying stem-shortening plant growth regulators to leaves on root elongation by seedlings of wheat, oat and barley: mediation by ethylene. Plant Growth Regulation 38(1): 51-9.

RODRIGUES, O. et al., Redutores de crescimento. Passo Fundo: Embrapa Trigo, 2003. 18 p html. (Embrapa Trigo. Circular Técnica, 14) Disponível em: <http://www.cnpt.embrapa.br/biblio/ci/ p_ci14.htm>. Acesso em: 22 abr. 2006.

Shah, L.; Yahya, M.; Shah, S.; Nadeem, M.; Ali, A.; Wang, J.; Riaz, M.W.; Rehman, S.; Wu, W.; Khan, R.M.2019. Improving lodging resistance: Using wheat and rice as classical examples. Int. J. Mol. Sci.20:4211.

STACHECKI, S.; PRACZYK, T.;
PRACZYK, K.2004. Adjuvant effects on plant growth regulators in winter wheat. J. Plant Prot. Res., 44(4):365376.

TAIZ, L.; ZEIGER, E. Fisiologia vegetal 2004. 3.ed. Porto Alegre: Artmed, 719 p.

Tripathi, S. C., Sayre, K. D., Kaul, J. N., and Narang, R. S. 2003. Growth and morphology of spring wheat (Triticum aestivum L.) culms and their association with lodging: effects of genotypes, $\mathrm{N}$ levels and ethephon. Field Crops Res. 84:271-290.

Zhang, Y., Su, S., Tabori, M., Yu, J., Chabot, D., Baninasab, B., et al., (2017). Effect of selected plant growth regulators on yield and stem height of spring wheat in Ontario. J. Agric. Sci. 9:30-421.

Behera U K, Sharma A R and Pandey H N. 2007. Sustaining productivity of wheatsoybean cropping system through integrated nutrient management practices on the Vertisols of central India. Plant and Soil297(2): 185-99

\section{How to cite this article:}

Naiyar Ali, P. Alam, Akhilesh Sah, Tajwar Izhar and Sanjay Kumar. 2021. Influence of Fertility Levels and Plant Growth Retardants on Growth and Productivity of Wheat (Triticum aestivum L.) in Jharkhand. Int.J.Curr.Microbiol.App.Sci. 10(01): 2779-2786.

doi: https://doi.org/10.20546/ijcmas.2021.1001.321 